\title{
QUALITY ASSESSMENT OF SOME EGYPTIAN AND SAUDI ARABIA HONEYS
}

\author{
A. A. Taha ${ }^{(1)}$, Naglaa E. Ghazala ${ }^{(1)}$, Amany S.M. Abou Lila ${ }^{(1)}$ \\ and H.M. Fathy ${ }^{(2)}$ \\ (1) Beekeeping Research Dept., Plant Protection Research Institute, Agricultural Research \\ Center, \\ (2) Economic Entomology Dept., Faculty of Agriculture, Mansoura Univ., Egypt. \\ *Correspondent author: amrotaha219@gmail.com
}

Received: Aug. 6, 2016

Accepted: Aug. 20, 2016

\begin{abstract}
The present study was conducted to evaluate the physicochemical properties of Egyptian cotton monofloral honey, and compare it with Saudi Arabia acacia (salam) honey. Cotton honey produced from cotton plants (Jossypium barbadense) by hybrid carniolan bees Apis mellifera carnica, while salam honey produced by Apis mellifera jamanitica bees. Three cotton honey samples were collected in (September 2014) from Sharkeia governorate, Egypt. In addition, three honey samples from salam plant (Acacia ehneberingiana) were collected during the blooming period (May, 2015) from Sabia district, the south region of Saudi Arabia. It could be concluded that salam honey had the highest viscosity values than the cotton honey presented 18000-16250 cps, respectively. The average results of water content were (22.2-17.2 \%), $\mathrm{pH}$ (3.81-3.79), total acidity (38.5-42.0 meq/ $\mathrm{kg})$, HMF (11.65-246 mg/kg), total amino acids (1.5-3.57 g/100g), total minerals content $(0.80-0.36 \%)$, for cotton and salam honeys, respectively. The average results of sugar composition for cotton and salam honeys were (42.66-34.3, 37.43-37.7 and 3.0-7.3\%) for Glucose, Fructose and Sucrose, respectively. For minerals content, $\mathrm{K}, \mathrm{Ca}, \mathrm{Na}$ and $\mathrm{Mg}$ were superior of all tested minerals in both of cotton and salam honeys. It's cleared that B1 and B3 vitamins did not detected in cotton honey. Also, B12 vitamin did not detected in salam honey. Cotton honey was only superior of vitamin B6 giving $0.031 \mathrm{mg} / 100 \mathrm{~g}$. Meanwhile, Vitamins B3, B5 and B9 was in high values in salam honey presented (0.6, 0.2 and $0.1 \mathrm{mg} / 100 \mathrm{~g})$, respectively. Finally, it could be concluded that honeys must correctly classified according to its floral origin. In addition, further studies are needed in order to investigate other floral origins to provide a robust model to classify honey samples from these regions.
\end{abstract}

Key words: Honey analysis, physiochemical characters, geographical origin.

\section{INTRODUCTION}

Determination of the standard criteria of food products is the most important process, since consumption, quality and validity of these products depend on it. Also, purity and contaminant- free food are other factors of great concern for consumer health. Honey is one of the most important global natural products. Honey comes in the first order of these products, since it has many benefits in foods, and medicine. (Serrano et al., 2007). Since honey types differ from one country to another and in different regions in the same country due to floral origin, soil composition and other factors consequently, quality criteria differ from one honey type to another, i.e. blossom honey is greatly different than the honeydew one. The reason for testing honey for quality control purposes is to verify the authenticity of the product and to reveal the possible presence of artificial components or adulterants, as well as to address processing and market needs (Krell, 1996). This requires not only determining the moisture and mineral content (ash), but also the levels of hydroxymethylfurfural (HMF), acidity, diastase activity, apparent sugars and water insoluble solids (Bogdanov et al., 2002). The 
Taha, et al.,

quality factor that is used in the international honey trade, besides its organoleptic characteristics (flavour, consistency and colour), is its chemical composition mainly moisture and HMF content, the diastase index, $\mathrm{pH}$, acidity as well as the content and proportion of the carbohydrates (sugars). The level of these indicators in a honey sample gives an indication of its quality (Muli et al., 2007). Honey composition is tightly associated to its botanical origin, which is closely related to the geographical area in which it is originated, because soil and climate characteristics determine melliferous flora as well as the presence of different minerals arising from soil, dust, etc. (Nelly et al., 2005). The floral origin of honey is an important characteristic in the evaluation of its quality (Baroni et al., 2006). Products from one region may attain a surplus value than similar products from another area. However, labeling of regional honey must be supported by analysis that confirms its provenance (Woodcock et al., 2007). In Egypt and Saudi Arabia, beekeeping is practiced in many areas, characterized by a remarkable richness of honey plants. In Saudi Arabia, the consumption of honey is increasing, since it is one of the principle ingredients in foods, as remedy and in natural mixtures (Alqarni, 2011). There are many types of honey (local and exotic) commonly consumed in Egypt and Saudi Arabia. Most of these honeys are traded without quality sign or reference to their origins and this may lead to honey adulteration and/or marketing non-standard honeys (Alqarni et al., 2012). So, comparing these honeys with quality standards is greatly required. The quality and biochemical properties of honey were related to honey maturity, production methods, climatic conditions, processing and storage conditions as well as the nectar source of honey (Crane, 1979). In many honey countries, there is a considerable difference in the price of honey depending on the botanical and geographical origin.
The main goal of this work was to characterize cotton honey from the honeybee Carniolan hybrid collected from Sharkeia governorate, Egypt, establishing associations among chemical variables and the production zone in comparing with acacia honey produced in south region of Saudi Arabia, from local colonies, Apis mellifera jemenitica. Thus, several physical and chemical parameters were evaluated.

\section{MATERIALS AND METHODS}

The present investigation was carried out at Food Safety\& Quality Control Lab, Faculty of Agriculture, Cairo University, Egypt during 2015, to study physical and chemical properties of the cotton and acacia (salam) honeys. Three cotton and acacia (Salam) honey combs represented three different local colonies were collected. For each parameter, the tests were replicated three times and the mean values were taken.

\section{Collecting honey sample:}

Cotton honey samples from cotton plants (Jossypium barbadense) cultivated in Sharkeia governorate, about $100 \mathrm{~km}$. east Cairo city, were collected from three different carniolan hybrid colonies Apis mellifera carnica. On the other hand, Unprocessed (raw) Salam honey from acacia trees (Acacia ehenbergiana) in Sabia region (Fig, 1) about 1800 km. south-west Riyadh city, Saudi Arabia, collected by cutting a honey comb from three different traditional colonies of sub species Apis mellifera jemenitica and put in light plastic pages kept in freezing conditions until analyses. Each Salam honey comb was squeezed with mesh to collect three honey samples. Meanwhile, cotton honey was collected from honey bee colonies kept in modern hives and extracted by the extractor and sieved. Then, each sample was kept in tied glass bottles (200 gm/colony) and put directly in the refrigerator until the experimental analysis was done. All samples were analyzed for the following properties: 

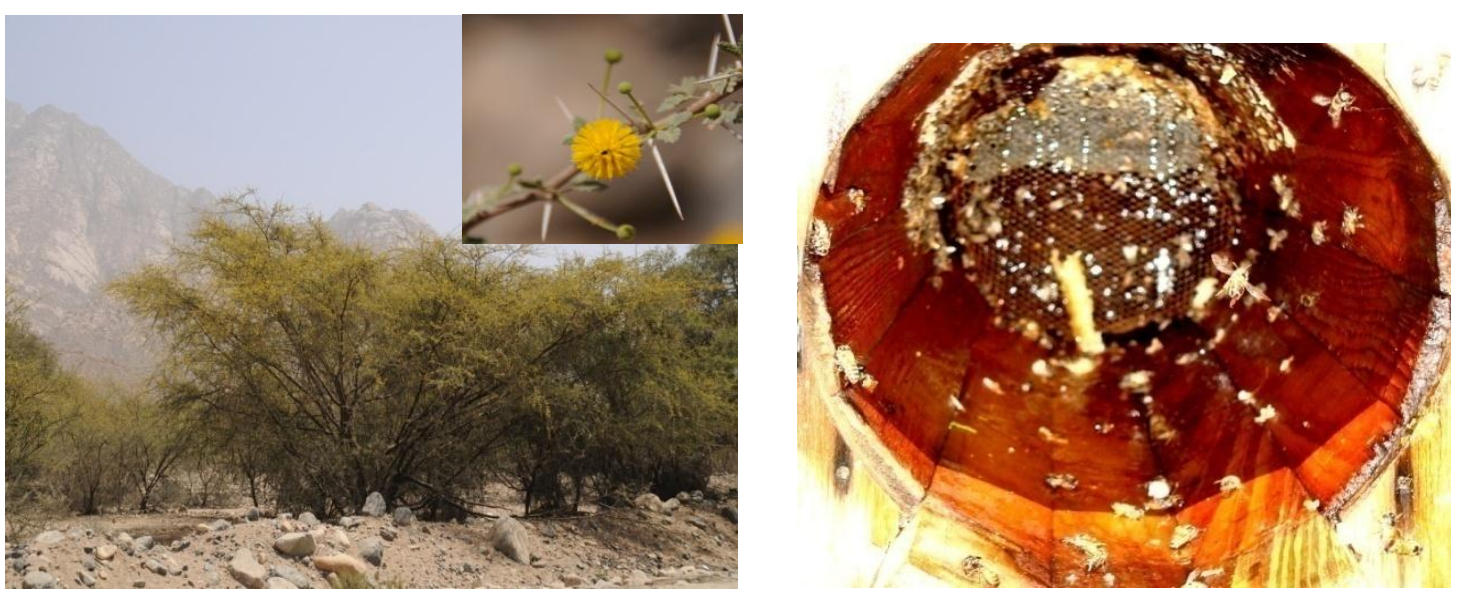

Fig (1). Comb honey in traditional hives and the flower of Salam tree in south region, KSA

\section{Analytical procedures:}

\section{a. Determination of Water content}

Determination of moisture content of honey was carried out by measurement its refractive index value (Abbe refractometer at $20 \stackrel{\circ}{ }$ C) (A.O.A.C, 1995).

\section{b. Determination of $\mathrm{pH}$, free acids and total acidity}

Based on the method of White et al. (1962). Reagents. Sodium hydroxide $0.05 \mathrm{~N}$. Hydrochloric acid $0.05 \mathrm{~N}$. Phenolphthalein indicator $1 \%(\mathrm{~m} / \mathrm{v})$ in ethanol, neutralized. Distilled water made carbon dioxide free, by boiling and subsequent cooling. Apparatus, $\mathrm{pH}$ meter, recently calibrated at $\mathrm{pH} 4$ and 8 , $10-\mathrm{ml}$ microburets. $10-\mathrm{ml}$ pipettes.

Procedure: The following titration is carried out, to $10 \mathrm{~g}$ sample of honey contained in a $250 \mathrm{ml}$ beaker; add $75 \mathrm{ml}$ $\mathrm{C} 02$ free distilled water. Dissolve honey and satire the solution with a magnetic stirrer. Place the electrodes of a $\mathrm{pH}$ meter in the solution and record the initial $\mathrm{pH}$. Then titrate the solution with $0.05 \mathrm{~N} \mathrm{NaOH}$. Add the $\mathrm{NaOH}$ at a rate so that individual drops just tend to merge into a steady stream (5.0 $\mathrm{ml} / \mathrm{min}$.). Stop adding $\mathrm{NaOH}$ when the $\mathrm{pH}$ reaches 8.5 . Immediately add $10.0 \mathrm{ml} 0.05$ $\mathrm{N} \mathrm{NaOH}$ By means of a $10 \mathrm{ml}$ pipette and without delay titrate back to $\mathrm{pH} 8.3$ by adding $0.05 \mathrm{~N} \mathrm{NaOH}$ by means of a $10 \mathrm{ml}$ pipet and without delay titrate back to $\mathrm{pH} 8.3$ by adding $0.05 \mathrm{~N} \mathrm{HCl}$ from a $10-\mathrm{ml}$ buret. The titration rate given is as rapid as found consistent with acceptable reproducibility. Titration to $\mathrm{pH} 8.5$ is equivalent to maintenance of phenolphthalein pink for 10 seconds, since the $\mathrm{pH}$ falls to 8.3 in that time. Expression of results: The amount of $\mathrm{NaOH}$ added from the burette, minus the 'blank' correction is considered the measure of the free acid present, and the amount of $\mathrm{HCl}$ used substrated from $10 \mathrm{ml}$ is measured of the lactone content. The sum of free acid and lactone is the total acidity.

\section{c. Determination of Hydroxymethylfurfural (HMF)}

It was determined according to Winkler (1955) as following, the reagents: Barbituric acid solution: $500 \mathrm{mg}$ barbituric acid was transferred to $100 \mathrm{ml}$ graduated flask using $70 \mathrm{ml}$ water. Then the flask placed in a hot water-bath until all amount of barbituric acid was dissolved, cool and make up to volume. P-toluidin solution: Weight out $10 \mathrm{~g} \mathrm{P}$ toluidin, analytical grade, and dissolved in about $50 \mathrm{ml}$ isopropanol by gentle warming in a water-bath then, transfer to a $100 \mathrm{ml}$ graduated flask with isopropanol and add 10 $\mathrm{ml}$ glacial acetic acid. Cool and make up to volume with isopropanol. Keep solution in the dark. Don't use for at least 24 hours. Distilled water (oxygen free): Nitrogen gas was passed through boiling distilled water. Then water is cooled. 


\section{Procedure:}

1. Preparation of test sample: $5 \mathrm{~g}$ of honey sample is weighted and dissolved without heating with oxygen free distilled water and transferred to a $25 \mathrm{ml}$ graduated flask and made up to volume (honey solution). The sample should be tested after preparation without delay.

2. Photometric determination: 2.0 $\mathrm{ml}$ of honey solution is pipetted into each of two test tubes and $5.0 \mathrm{ml} \mathrm{P}$-toluidine solution is added to each. Into one test tube $1 \mathrm{ml}$ water is pipetted and into the other $1 \mathrm{ml}$ barbituric acid solution and both mixtures are shaken. The tube with added water, serves as the water blank. The addition of reagents should be done without pause and should be finished in about 1-2 min. The extinction of the sample is read against the blank at $550 \mathrm{~nm}$ using a $1-\mathrm{cm}$ cell, immediately the maximum value is reached.

3. Calculation and expression of results: The method may be calibrated by using a standard of HMF standardized by dissolving commercial or laboratory prepared HMF and assaying spectrophotometrically. The equation by which results may be roughly worked out is:

$\mathrm{mg} / 1000 \mathrm{~g} \mathrm{HMF}=$ absorbance /thickness of layer *192 .

Results are expressed as mg HMF/Kg honey.

\section{d. Determination of nitrogen content, Total Amino Acids and Proline:}

Kjeldahl - Digestion unit, Vapodest 20s Distillation unit was used to determine nitrogen content. For total amino acids, acids hydrolysis of honeys was carried out according to Block et al. (1958). Instrument used, UV/Vis. Spectrophotometry, Jenway, England. Wave length $(650 \mathrm{~nm}$.). Determination proline content was done by using Harmonized methods of International honey commission (2009). Determination of proline. P. 59. Instrument used, UV/Vis.
Spectrophotometry, Jenway, England. Wave length $(510 \mathrm{~nm}$.).

\section{e. Determination of Minerals:}

Potassium, sodium and calcium were determined by flame photometer apparatus. Meanwhile, microelements (Mg, Zn, Mn, Fe, $\mathrm{Cu}$, Co, Ni) were determined by Atomic Absorption 157 (International Labs).

\section{f. Determination of Invertase activity:}

Invertase activity was determined using the Siegenthaier method. As a substrate is used $p$ - Nitrophenyl-alfa-D-glucopyranosid (pNPG) which is decomposed by invertase from honey to glucose and $p$-nitrophenol.

By modifying $\mathrm{pH}$ to 9.5 the enzymatic reaction is stopped and at the same time nitrophenol is transformed to nitrophenal anion which is equivalent to the transformed substrate and is determined spectrophotometrically at $400 \mathrm{~nm}$ (UVA/IS Spectometer Lambda I I, Perkin Elmer, USA). The honey invertase activity was calculated from the measured absorbency by multiplying by the factor of 158.94 and calculated to a kilo of honey $(\mathrm{U} / \mathrm{kg})$. Then the value was expressed as invertase number (IN). The IN indicates the amount of sucrose per gram hydrolysed in $1 \mathrm{~h}$ by the enzymes contained in $100 \mathrm{~g}$ of honey under test conditions (Bogdanov et al., 1997).

\section{g. Determination of Diastase activity:}

Determination of diastase activity was evaluated spectrophotometrically based on the method of Schade et al. (1958) using the Shade method (UVA/IS Spectometer Lambda II, Perkin Elmer, USA). The diastase activity is calculated as diastase number (DN). DN expresses units of diastase activity (Gothe unit). One unit is defined as the amount of enzyme that will convert $0.01 \mathrm{~g}$ of starch to the prescribed end-point in $1 \mathrm{~h}$ at $40{ }^{\circ} \mathrm{C}$ under the conditions of test (Bogdanov et al., 1997). 


\section{h. Determination of glucose oxidase}

Based out the method of White and Subers (1963). Reagents, 0.4 phosphate buffer $\mathrm{pH} 6.5$ Peroxide reagent. Dilute $5 \mathrm{ml}$ buffer, and $10 \mathrm{mg}$ 0-dianisidine (3,3dimethoxybenz iodine), 'Fluka A, G' in $2 \mathrm{ml}$ $95 \%$ ethyl alcohol at $200 \mathrm{ml}$ with distilled water. Make fresh daily. Peroxidase, $2 \mathrm{mg}$ peroxidase (Boehringer, Mannheim) is dissolved in $50 \mathrm{ml} 0.01 \mathrm{M}$ phosphate buffer $\mathrm{pH}$ 6.5. A tissue culture Rollordrum operating at $20 \mathrm{rpm}$. in an incubator at $37^{\circ} \mathrm{C}$ is used. Narrow-mouth, screw-neck 8-0z. $(225 \mathrm{ml})$ round flint glass bottles are used, with moulded plastic screw.

Procedure: Weight under minimal illumination $5 \mathrm{~g}$ honey to the nearest $0.01 \mathrm{~g}$, add $5 \mathrm{ml}$ buffer, transfer to a $25-\mathrm{ml}$ volumetric flask, and make to volume with ; distilled water. After the buffer is added the enzyme, is no longer light-sensitive, and ordinary laboratory illumination may be used. To the $8-0 z$ bottle is added $10 \mathrm{ml}$ honey solution and $10 \mathrm{ml}$ distilled water. The bottle is capped and waned to $37^{\circ} \mathrm{C}$ in a bath, without agitation. It is placed in the roller drum at $20 \mathrm{rpm} ., 37^{\circ} \mathrm{C}$, for 1 hour.

Three test-tubes are meanwhile prepared for each sample: two containing $6.0 \mathrm{ml}$ reagent and sufficient water to make $2.0 \mathrm{ml}$ when added to' the sample volume, and the third (blank) tube containing water in place of the reagent. After the 1 hour's incubation, the bottle is removed, and an appropriate volume $(0.1$ to $2.0 \mathrm{ml}$ depending on peroxide content) of the incubated solution is added to each tube, the contents mixed, and the absorbance at 400 run is determined between 5 and 10 minutes after the final mixing, and with a liner curve between the absorbance and H202'. The results of the assay was expressed as micrograms hydrogen peroxide accumulated per hour per gram of honey under the experimental conditions.

\section{i. Determination of Sugars in honey: Instrument used: HPLC Knauer,}

Germany equipment with two pumps, R1 detector, column oven and clarity-chrom software. Instrument condition: Column: The flow rate was at adjusted at $1.5 \mathrm{ml} / \mathrm{min}$, the column used was Luna $\mathrm{NH}_{2}$ column for carbohydrate analysis, the column oven temperature kept constant at $40{ }^{\circ} \mathrm{C}$, the RI detector operated at room temperature, the mobile phase was acetonitrile: HPLC grade: water $(80: 20, v: v)$. Sample preparation: $5 \mathrm{~g}$ of sample were dissolved in $12 \mathrm{ml}$ methanol HPLC grade, Quantitatively transferred to measuring flask $50 \mathrm{ml}$ completed to the mark with HPLC grade water, sonicated for 20 min, Filtering through PTFE filter $(0.2 \mathrm{~mm})$, kept at $0{ }^{\circ} \mathrm{C}$ until analysis. Standard preparation: Pipette $25 \mathrm{ml}$ methanol into a $100 \mathrm{ml}$ calibrated flask. Depending on the sugars to be analyzed, dissolve the amounts detailed below in approximately $40 \mathrm{ml}$ water and transfer quantitatively to the flask and fill to the mark with water. Fructose: $2.000 \mathrm{~g}$; glucose: $1.500 \mathrm{~g}$; sucrose: $0.250 \mathrm{~g}$; maltose: 0.150g. (Codex Alimentarius, 1993) in Fig. 2.

\section{j. Determination of water soluble vitamins (WSV) in honey: \\ Instrument used: HPLC Knauer,} Germany equipment with two pumps, UV detector, column oven and clarity-chrom software. Instrument condition: Column: Kinetex 2.6u C18 100x 4.6mm. the temperature kept constant at $22 \mathrm{C}^{\circ}$, flow rate $0.5 \mathrm{ml} / \mathrm{min}$. Mobile phase, $50 \mathrm{~m} \mathrm{M}$ phosphate buffer, $\mathrm{pH}=2.8$ : Methanol $(90: 10)$, wave length $254 \mathrm{~nm}$. Sample preparation: About $5 \mathrm{~g}$ sample was weight accurately about $0.001 \mathrm{~g}$ sample were dissolved in $5 \mathrm{ml}$ HPLC grade water sonicated for $15 \mathrm{~min}$, then diluted to $50 \mathrm{ml}$ by HPLC grade water, filtered by $0.25 \mu$ disposal PTFE syringe filter. Standard preparation: A stock solution of $2.5 \mathrm{mg}$ of vitamin $\mathrm{B} 12+4 \mathrm{mg}$ of vitamin $\mathrm{B} 6+5 \mathrm{mg}$ of vitamin $\mathrm{B} 1+1 \mathrm{mg}$ of folic acid+ $20 \mathrm{mg}$ of nicotinamide (B3) $+6 \mathrm{mg}$ of $\mathrm{D}$ panthenol (B5) and $10 \mathrm{mg}$ of Orotic acid (B13) were dissolved in $2 \mathrm{ml}$ HPLC grade water, then $1 \mathrm{ml}$ of this solution was sonicated in $5 \mathrm{ml} \mathrm{HPLC}$ grade water for 15 min. then filtered through $0.45 \mu$ disposal PTFE syringe filter (Ciulu et al., 2011) in Fig 3. 


\section{RESULTS AND DISSCUSSION}

Relationship between geographical origin of production honeys and physical and chemical activity was illustrated in Tab. (1-5) and Fig. (2-5).

\section{Physical properties:}

Results in Table (1) show the major physical and chemical properties of the collected honey samples from Egypt and Saudi Arabia.

\section{Water content}

The initial moisture content of both cotton and salam honeys were measured. Data in table (1) showed that Saudi salam honey did not exceed the 20\% allowed by (Codex Alimentarius, 1993). Average moisture content was $17.2 \%$ for salam honey, meanwhile cotton honey exceed the allowed by (Codex Alimentarius, 1993) giving $22.2 \%$.

\section{pH}

The $\mathrm{pH}$ values of salam and cotton honey samples ranged from 3.79 to 3.81 table (1), respectively. These findings agreed with Bogdanov (1999) and Codex Alimentarius (1998) which specified a pH range of 3.42 to 6.10 . This parameter is of great importance during extraction and storage of honey as it influences the texture, stability and shelf life of honey (Terrab et al., 2004). According to Kamal et al. (2002) difference in $\mathrm{pH}$ may be due to variation of different acids and minerals present in honey. Higher $\mathrm{pH}$ values obtained from honey harvested using traditional method could be as a result of fermentation due to inappropriate method of harvesting (Babarinde et al., 2011). All of the investigated Egyptian and Saudi honey samples were acidic $(\mathrm{pH} 3.53$ - 4.03) (Table 1) and were within the limit $(\mathrm{pH} 3.4$ to 6.1) that indicates freshness (Moniruzzaman et al., 2013).

\section{Viscosity}

The values for viscosity obtained were $16250 \mathrm{cps}$ to $18000 \mathrm{cps}$ for cotton and salam honeys, respectively. As water content was used as an indicator of viscosity, there are reflex relationship between water content and viscosity. The results of Saudi honey are consistent with those reported by Al-qarni et al., (2012) they found that all the tested Saudi honeys had relatively low water content (12.12\%$17.32 \%)$ compared to Egyptian honeys which showed high water content (20.12\%). Abu- Tarboush et al. (1992) and Kaakeh and Gade-Elhak (2005) attributed this low level of water content to the dry weather in the area of honey production. Moreover, water content in honey is responsible for its stability against fermentation and granulation.

Table (1): Mean values of some physical characteristics of cotton and salam honeys

\begin{tabular}{|l|c|c|c|c|c|c|c|c|c|c|}
\hline $\begin{array}{c}\text { Physical } \\
\text { characters }\end{array}$ & $\begin{array}{c}\text { Water } \\
\text { content } \\
\mathrm{g} / 100 \mathrm{~g} \\
(\%)\end{array}$ & $\mathrm{pH}$ & $\begin{array}{c}\text { Viscosity } \\
\mathrm{cps}\end{array}$ & $\begin{array}{c}\text { Total } \\
\text { acidity } \\
\mathrm{meq} / \mathrm{Kg}\end{array}$ & $\begin{array}{c}\text { Free } \\
\text { Acidity } \\
\mathrm{meq} / \mathrm{Kg}\end{array}$ & $\begin{array}{c}\mathrm{HMF} \\
\mathrm{mg} / \mathrm{kg}\end{array}$ & $\begin{array}{c}\text { Nitrogen } \\
\%\end{array}$ & $\begin{array}{c}\text { Total } \\
\text { amino } \\
\text { acids } \\
\mathrm{g} / 100 \mathrm{~g}\end{array}$ & $\begin{array}{c}\text { Proline } \\
\mathrm{mg} / \mathrm{kg}\end{array}$ & $\begin{array}{c}\text { Total } \\
\text { minerals } \\
\%\end{array}$ \\
\hline $\begin{array}{l}\text { Cotton } \\
\text { Egypt }\end{array}$ & 22.2 & 3.81 & 16250 & 38.50 & 35.0 & 11.65 & 0.095 & 1.50 & 457.0 & 0.80 \\
\hline $\begin{array}{l}\text { Salam } \\
\text { KSA }\end{array}$ & 17.2 & 3.79 & 18000 & 42.0 & 38.0 & 246.0 & 0.16 & 3.57 & 1024 & 0.36 \\
\hline
\end{tabular}



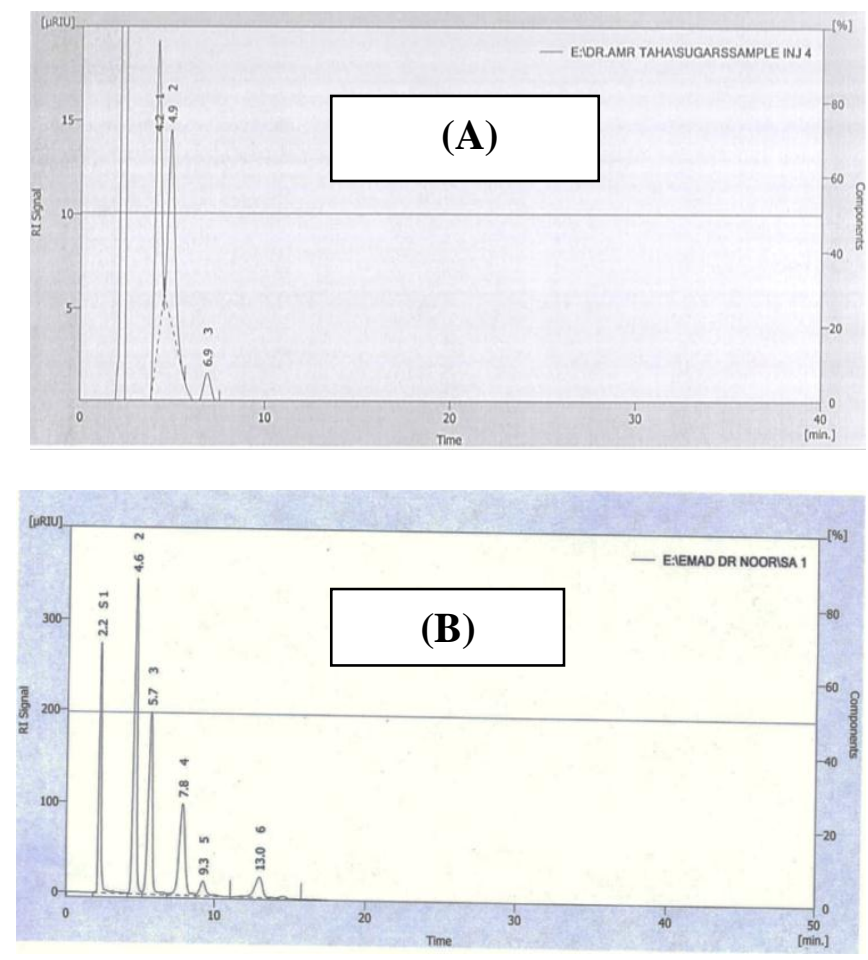

Fig (2). Estimation of some cotton (A) and salam (B) honey sugars
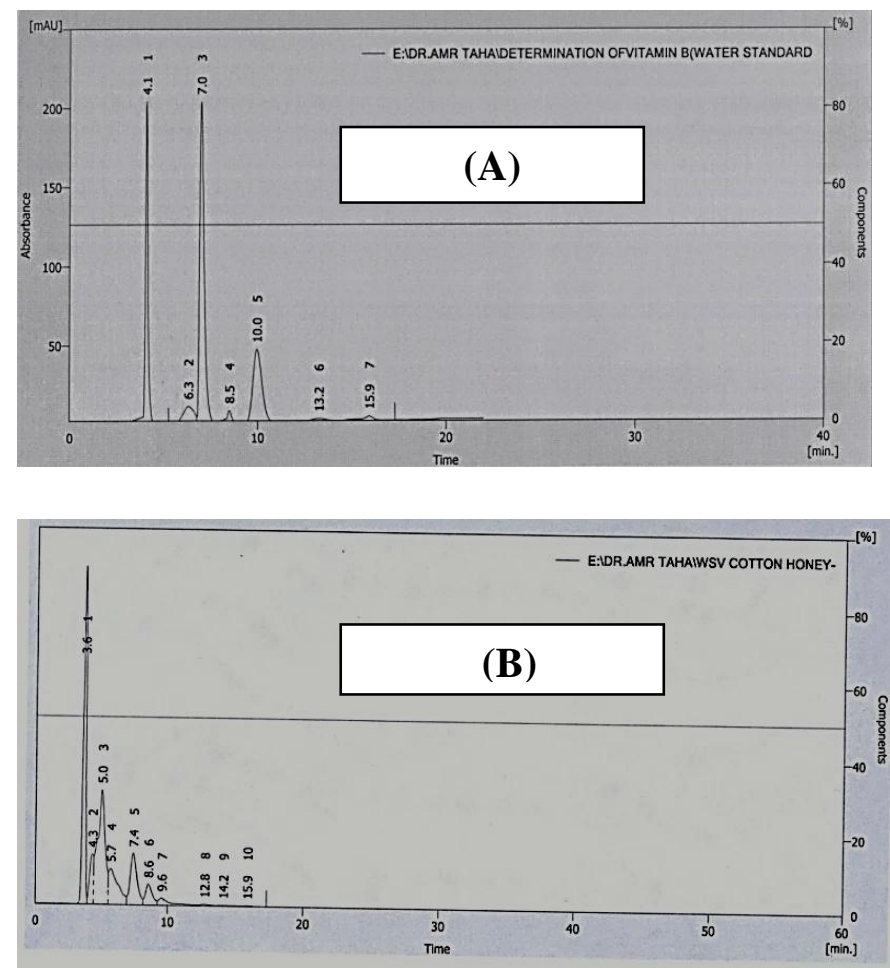

Fig (3). Estimation of some cotton (A) and salam (B) honey vitamins 


\section{Total acidity}

The values of total acidity obtained ranged from $38.5 \mathrm{meq} / \mathrm{kg}$ to $42 \mathrm{meq} / \mathrm{kg}$ for cotton and salam honey, respectively. It's obvious that cotton honey total acidity value is within the range specified by Codex Alimentarius (1998) with a maximum limit of $40 \mathrm{meq} / \mathrm{kg}$ and this indicated the absence of undesirable fermentation (Babarinde et al., 2011). Meanwhile, the value for salam honey exceed the maximum limit or standard giving $42.0 \mathrm{meq} / \mathrm{kg}$ for total acidity. Total acidity indicates the history of honey and possible alcohol and acid production by bacterial fermentation (Rodgers, 1979). Since some honeys have a higher natural acidity, Al-Doghairi et al. (2007) found a wide range of total acidity between (9.12 to $93.02 \mathrm{meq} / \mathrm{kg}$ ) for Saudi honeys. Moreover, higher acidity value in honey harvested using traditional method could be due to floral sources. In addition, high value of acidity could also be due to fermentation of honey due to inappropriate method of harvesting which involved immature honey combs and brood that accelerate rate of fermentation. According to Costa et al. (1999) Xerotolerant yeast may also be responsible for high total acidity. Honey samples were therefore analyzed to determine the amount of free acid present. The values of free acidity obtained ranged from $35 \mathrm{meq} / \mathrm{kg}$ to $38 \mathrm{meq} / \mathrm{kg}$ for cotton and salam honey, respectively.

\section{Hydroxymethylfurfural (HMF)}

From the results in Table (1), the HMF content of the different honey samples ranged from $11.65 \mathrm{mg} / \mathrm{kg}$ to $246 \mathrm{mg} / \mathrm{kg}$ for cotton and salam honeys, respectively. The Saudi salam honey had very high HMF content being $246 \mathrm{mg} / \mathrm{kg}$ as its exceed the maximum limit or standard of $80 \mathrm{mg} / \mathrm{kg}$ specified by Codex Alimentarius (1993). However, the value of HMF in honey harvested using traditional method was higher than the value in honey harvested using modern method (Babarinde et al., 2011). In addition Tosi et al. (2002) reported that thermal treatment can increase HMF content of honey. Overheating of honey sample during processing or storage for very long period could lead to conversion of sugars to HMF (Saxena et al., 2010). Therefore, honey treatment temperature and time must be limited when pasteurizing and stabilizing. According to Fallico et al. (2004), HMF concentration in honey is also related to honey composition ( $\mathrm{pH}$, acidity) particularly at low heating temperatures. Moreover, Alqarni, et al. (2012) indicated that 4 Saudi honeys had very high HMF content ranged from $101.80 \mathrm{mg} / \mathrm{kg}$ to 258.72 $\mathrm{mg} / \mathrm{kg}$, respectively.

\section{Nitrogen content}

Results in Table (1) show the value of nitrogen content as percentages. The nitrogen content percentage for cotton honey was $0.095 \%$ and $0.16 \%$ for salam honey. The nitrogen content which is indication of the presence of protein was found highest in salam honey harvested using traditional method. This finding is contrary with Babarinde et al. (2011) as they stated that nitrogen content in modern harvested honey was found higher than that in traditional harvested honey. Meanwhile, our result implies that more nitrogen content is retained in traditional harvesting method. Total protein content in honey can vary widely between $0.02 \%$ and $1.0 \%$ (Kaakeh and Gade-El Hak, 2005). High value of protein content more than $2 \mathrm{mg} / \mathrm{g}$ are due to high content of floral origin (Azeredo et al., 2003).

\section{Total amino acids and Proline}

Data presented in Table (1) illustrated both total amino acids and proline existing in cotton and salam honeys. Taha and Eissa (2011) found that proline is the most important from a quantitative point of view of amino acids. Salam honey was superior of total amino acids presented $(3.57 \mathrm{~g} / 100 \mathrm{~g}$ ). Meanwhile, cotton honey presented (1.5 $\mathrm{g} / 100 \mathrm{~g})$. Quantitative of proline amino acid existing in salam honey was more than twice 
in cotton honey presented $1024 \mathrm{mg} / \mathrm{kg}$ and $457 \mathrm{mg} / \mathrm{kg}$, respectively. It has long been recognized from the literature Gilbert et al. (1981) and Goodall et al. (1995) that amino acids profiles could be used as chemical markers for botanical and geographical origin of honey.

\section{Total minerals (Ash) content}

Ash content and some minerals elements in both cotton and salam honeys were analyzed as its presents the minerals content of the honey. The values of the ash content of the honey samples ranged between $0.36-0.80 \%$ (Table, 1) in salam and cotton honeys, respectively. The ash content values ranged from $0.095 \%$ to $0.518 \%$ (Adebiyi et al., 2004). Moreover, Saxena et al. (2010) reported a range of $0.03 \%-0.43 \%$ ash content in some Indian honeys. Meanwhile, Taha and Eissa (2011) reported the range of ash content from $0.03 \%$ to $0.26 \%$ for Egyptian and Libyan honeys of different botanical origin. According to White and Landis (1980), dark honey is higher than lighter honey in ash content (minerals) and contains significant qualities of minerals.

In addition, the resultis Table (2) ten different types of minerals Calcium $\mathrm{Ca}$, Sodium $\mathrm{Na}$, Potassium K, Magnesium Mg, Zinc Zn, Manganese Mn, Ferris Fe, Cupper $\mathrm{Cu}$, Cobalt $\mathrm{Co}$ and Nickel $\mathrm{Ni}$ were detected. For cotton honey, $\mathrm{K}, \mathrm{Mg}, \mathrm{Ca}$ and $\mathrm{Na}$ content were superior of all tested minerals presents 2018, 327, 287 and 153 ppm, respectively. For salam honey, $\mathrm{Ca}, \mathrm{Na}$ and $\mathrm{K}$ content were superior of all tested minerals presents 625, 625 and 438 ppm, respectively. In addition, each of $\mathrm{Fe}, \mathrm{Cu}, \mathrm{Co}$ and $\mathrm{Ni}$ were not detected in salam honey. The same trend was observed for cotton honey for Co and
$\mathrm{Ni}$. In general, it can be consider that the presence of these minerals is indication of contamination during processing, shipping or storage due to the use of steel galvanized containers (Corbella and Cozzolino, 2006). It's obvious that minerals in cotton honey exceed by 1.6 time minerals in salam honey. Furthermore, metal concentrations in the studied honeys were in safe levels for human consumption (Baroni et al., 2009).

\section{Enzymes in honey samples}

Data in Table (3) showed the invertase, diastase and Glucose oxidase activity values for cotton and salam honey samples. The invertase activity in salam and cotton honeys was 4.60 and $74.86 \mu / \mathrm{kg}$, respectively. The higher value of invertase in cotton honey, the same trend was observed in honeydew honeys which gets by means of salivary glands and the gut of plant-sucking insects (Crane, 1990). The reduction in invertase activity in salam honey giving $4.6 \mu / \mathrm{kg}$ may be due to heating processes during honey bottling or transport as invertase is more heat-sensitive than diastase (Beckmann et al., 2011). These results are in agreement with Vorlova and Pridal (2002) they found that invertase values in acacia honey was in range 9.0 to 16.3. In addition, diastase number (DN) in cotton honey was in an acceptable range not less than 8 on Goth standard presented $16.9 \mu / \mathrm{g}$. On the other hand, in salam honey diastase number DN was below the standard giving $6.50 \mu / \mathrm{g}$. The relation of both enzymes expressed by the invertase/diastase ratio is cleared from Table (3). The invertase/diastase ratio for filtered cotton honey was 4.4. On contrary, the invertase/diastase ratio for salam honey was a much smaller presented 0.707 .

Table (2). Minerals composition of cotton and salam honeys (ppm).

\begin{tabular}{|l|c|c|c|c|c|c|c|c|c|c|}
\hline Minerals & $\mathbf{K}$ & $\mathbf{C a}$ & $\mathbf{N a}$ & $\mathbf{M g}$ & $\mathbf{Z n}$ & $\mathbf{M n}$ & $\mathbf{F e}$ & $\mathbf{C u}$ & $\mathbf{C o}$ & $\mathbf{N i}$ \\
\hline Cotton & 2018.0 & 287.0 & 153.0 & 327.0 & 5.7 & 3.3 & 22.4 & 1.49 & 0.0 & 0.0 \\
\hline Salam & 438.0 & 625.0 & 625.0 & 13.0 & 4.0 & 2.0 & 0.0 & 0.0 & 0.0 & 0.0 \\
\hline
\end{tabular}


Taha, et al.,

Table (3). Values of some enzymes characteristics of cotton and salam honeys

\begin{tabular}{|c|c|c|c|}
\hline Enzymes & $\begin{array}{c}\text { Invertase } \\
\mu / \mathbf{k g}\end{array}$ & $\begin{array}{c}\text { Diastase } \\
\mu / \mathbf{g}\end{array}$ & $\begin{array}{c}\text { Glucose oxidase } \\
\mu / \mathbf{g}\end{array}$ \\
\hline Cotton & 74.86 & 16.9 & 0.17 \\
\hline Salam & 4.60 & 6.50 & 0.07 \\
\hline
\end{tabular}

The activity of diastase ( $\alpha-, \quad \beta-, \quad \gamma^{-}$ amylase) is the important quality parameter of honey and the diastase number must not be less than or equal to 8 . Diastase is used as a marker to evaluate the freshness or the heat damage of honey. When honey is adulterated by addition of inverted sucrose or hydrolysed starch namely high fructose corn syrup (HFCS), then such dilution of honey leads to the reduction of diastase number. Such adulteration can be masked by addition of foreign amylases. Enzymes are the most important and also the most interesting honey components. They are accountable for the conversion of nectar and honeydew to honey, and serve as a sensitive indicator of the honey treatment. In some countries, the specification of enzymes is a binding legal indicator (Bogdanov et al., 1987; Codex Alimentarius, 1993). The results suggest that the proteolytic enzymes of honey can significantly change honey protein profile and thereby strongly influence quality and nutritional value of honey (Rossano et al., 2012).

\section{Sugar composition}

The range and mean levels of Glucose, Fructose, Sucrose and Maltose in both salam and cotton honeys were analyzed (Table, 4).

The sucrose content of honey samples giving 3\% for cotton honey harvested using modern method. On the other hand, the sucrose content of salam honey gave $7.3 \%$. The presence of sucrose below $5 \%$ as specified by Codex Alimentarius (1998) indicates that the bees were not artificially fed with sugar. Although the analysis of sugars in honey has to a large extent focused on honey adulteration, oligosaccharide profiles are also a potential tool to indicate botanical and geographical origin. Besides the two main constituents of honey, which are glucose and fructose, there are about 25 other oligosaccharides (disaccharides, tri saccharides and tetrasaccharides), which occur as relatively mino components. In Table (4) the mean levels percentage of glucose, fructose, maltose and sucrose in both salam and cotton honey samples were analyzed. Maltose was selected as oligosaccharide parameter to be used in the classification of Saudi and Egyptian honeys. Maltose was not found in salam honey samples. This finding is in agreement with Senyuva et al. (2009) they found that maltose was not found in either citrus or sunflower Turkish honey samples. Meanwhile, cotton honey was found to contain maltose at percentage $1.92 \%$, but it is difficult to draw conclusions from single samples. Reducing sugars which include mainly glucose and fructose are the major constituent of honey (Kucuk et al., 2007). A lime honey from Romanian had $42.49 \%$ of combined glucose and fructose in all the honey weight (Finola et al., 2007). Crane (1990) reported that glucose and fructose which are the two major and primary sugars in honey are the main factor in determining the tendency of honey to crystallize.

Generally, the higher the glucose, the faster honey crystallizes, and the higher the fructose, the slower it crystallizes. This finding supported by Bogdanov (1993) stated that honey with a glucose content of $30 \%$ or more tends to granulate readily. 
Samples with glucose to water ratios of 1.7 or less were considered non- granulating, while samples with ratios of 2.1 or more predicted rapid granulation (White, 1975). From the result in table (4), the salam Saudi honey samples had higher values of fructose $37.7 \%$, thus indicating they are less susceptible to early crystallization and this honey is of good quality (Kaakeh and GadelHak, 2005). On the other hand, glucose sugar was higher than fructose in cotton Egyptian honey giving $42.66 \%$ and $37.43 \%$, respectively. Other factors that may cause crystallization include higher molecular weight sugars (oligosaccharides), acidity and available water (Crane, 1990).

\section{Water-soluble vitamins (WSV)}

According to Table (4) average concentration of water-soluble vitamins $(\mathrm{mg} / 100 \mathrm{~g})$ of salam and cotton honeys of different botanical origin were detected. Each of vitamin B1 (Thiamine), B3 (Nicotinic acid), B5 (Pantothenic acid), B6 (Pyridoxine), B9 (Folic acid), B12 (Cobalamin), B13 (Orotic acid) was detected.

Results in Table (5) report the amount of the water soluble vitamin (WSV) in all honey samples analyzed. Data in table (5) showed some vitamins characteristics for cotton and salam honeys. It's cleared that B1 and B3 vitamins did not detected in cotton honey.
Also, B12 vitamin did not detected in salam honey. Meanwhile, Vitamins B3, B5 and B9 was in high values in salam honey presented (0.6, 0.2 and $0.1 \mathrm{mg} / 100 \mathrm{~g}$ ), respectively. Cotton honey was only superior of vitamin B6 giving $0.031 \mathrm{mg} / 100 \mathrm{~g}$. Further, data confirmed that cotton honey is not a vitamin rich food. Interestingly, the concentration of vitamin B3 (Niacin) was observed to be as high as $0.600 \mathrm{mg} / 100 \mathrm{~g}$ and it seemed to be strongly dependent on the botanical origin of the honey samples (Ciulu et al., 2011).

It can be presume an influence of the origin of the samples on the concentration of these analytics as well, but the low number of samples analyzed keeps us from drawing such a conclusion at this time. In the case of honey, has been shown that commercial filtration reduces its vitamin content due to the almost complete removal of pollen. Another factor that causes the loss of vitamins in honey is the oxidation of ascorbic acid by hydrogen peroxide produced by glucose oxidase (Crane, 1979). In conclusion, although the concentration of WSV in honey may be too low to generate interesting the field of nutrition, its potential correlation to the botanical origin of the samples may prove useful to determine the origin of honeys.

Table (4). Mean values of some sugars characteristics of Salam honey analysis

\begin{tabular}{|l|c|c|c|c|}
\hline \multicolumn{1}{|c|}{ Sugar } & $\begin{array}{c}\text { Glucose } \\
\%\end{array}$ & $\begin{array}{c}\text { Fructose } \\
\%\end{array}$ & $\begin{array}{c}\text { Sucrose } \\
\%\end{array}$ & $\begin{array}{c}\text { Maltose } \\
\%\end{array}$ \\
\hline Cotton & 42.66 & 37.43 & 3.0 & 1.92 \\
\hline Salam & 34.3 & 37.7 & 7.3 & N/A \\
\hline
\end{tabular}

$\mathrm{N} / \mathrm{A}=$ Non detected

Table (5). Values of some vitamins characteristics $(\mathrm{mg} / 100 \mathrm{~g})$ of cotton and salam honeys.

\begin{tabular}{|l|c|c|c|c|c|c|c|}
\hline \multicolumn{1}{|c|}{ Vitamins } & B1 & B3 & B5 & B6 & B9 & B12 & B13 \\
\hline Cotton & N/A & N/A & 0.055 & 0.031 & 0.002 & 0.001 & 0.0015 \\
\hline Salam & 0.02 & 0.600 & 0.20 & 0.017 & 0.10 & N/A & 0.001 \\
\hline
\end{tabular}




\section{Acknowledgement}

The authors wish to thank all the staff members of Food Safety \& Quality Control Lab., Faculty of Agriculture, Cairo University for physical and chemical analysis of honey samples. Also, indebted thanks revealed to Prof. Dr. Ahmed A. Al-Ghamdi for his kind and unlimited help during collecting the Saudi Arabia honey samples.

\section{REFERENCES}

A. O. A. C. (1995). Official methods of analysis. (16th ed).Washington, DC: USA: Ass. Off. Ana. Chem..

Abu-Tarboush, H.M., H.A. Al-Kahtani and M.S.A. El-Sarrag (1992). Floral-type identification and quality evaluation of some honey types. Food Chem., 46, 1317.

Adebiyi, F.M., I. Akpan, E.I. Obiajunwa and H.B. Olaniyi (2004). Chemical/Physical Characterization of Nigerian Honey. Pakistan Journal of Nutrition, 3 (5): 278281.

Al-Doghairi, M.A., S. Al-Rehiayani, G.H. Ibrahim and K.A. Osman (2007). Physicochemical and antimicrobial properties of natural honeys produced in Al-Qassim region, Saudi Arabia. Met. Environ. Arid Land Agric. Sci., 18 (2): 318.

Alqarni, A.S. (2011). Beekeeping in Saudi Arabia: Current and Future (in Arabic), first ed., Saudi Society for Agricultural Sciences, King Saud Univ., Riyadh, 40 (21).

Alqarni, A.S., A.A. Owayss and A.A. Mahmoud (2012). Physicochemical characteristics, total phenols and pigments of national and international honeys in Saudi Arabia. Arabian Journal of Chemistry, http://dx.doi.org/10.1016/j.arabjc.2012.11. 013.

Azeredo, L.C., S.R. De Souza, M.A.A. Azeredo and V.M.L. Dutra (2003). Protein contents and physicochemical properties in honey samples of Apis mellifera of different floral origins. Food Chem., 80: 249-254.

Babarinde, G.O., S.A. Babarinde, D.O. Adegbola and S.I. Ajayeoba (2011). Effects of harvesting methods on physicochemical and microbial qualities of honey. J. Food Sci. Technol., 48 (5): 628-634.

Baroni, M.V., M.L. Nores, M.P. Díaz, G.A. Chiabrando, J.P. Fassano, C. Costa and D.A. Wunderlin (2006). Determination of volatile organic compound patterns characteristic of five unifloral honey by solid-phase microextraction-gas chromatography-mass spectrometry coupled to chemometrics. J. Agric. Food Chem., 54: 7235-7241.

Baroni, M.V., C. Arrua, M.L. Nores, P. Fayé, M.P. Diaz, G.A. Chiabrando and D.A. Wunderlin, (2009). Composition of honey from Cordoba (Argentina): Assessment of North/South provenance by chemometrics. Food Chemistry, 114: 727-733.

Beckmann, K., G. Beckh, C. Luellmann and K. Speer (2011). Characterization of filtered honey by electrophoresis of enzyme fractions. Apidologie, 42:59-66. doi: 10.1051/apido/2010036.

Bogdanov, S. (1993). Liquefaction of honey. Apiacta XXVIII, 4-10.

Bogdanov, S. (1999). Honey quality and international regulatory standards: Review by the International Honey Commission. Bee World, 80: 61-69.

Bogdanov, S., K. Riender and M. Ruegg (1987). Neue Qualitätskriterien bei Honiguntersuchungen. Apidologie, 18: 267-278.

Bogdanov, S., P. Martin and C. Lullman (1997). Harmonised method of the European Honey Commission. Apidologie (extra issue), pp: 59.

Bogdanov, S., P. Martin and C. Lullmann (2002). Harmonised methods of the international honey commission. FAM, Liebefeld: Swiss Bee Research Centre.

Ciulu, M., S. Solinas, I. Floris, A. Panzanelli, M.I. Pilo, P.C. Piu and Sanna N. Spano (2011). RP-HPLC determination of watersoluble vitamins in honey. Talanta, 83 (3): 924-929.

Codex Alimentarius Commission, CAC (1998). Codex Alimentarious Draft revised for honey. CAD CX P 5/102, CI, 1998/12-S, FAO, Rome, Italy.

Codex Alimentarius Standard for honey (1993). Standard for Honey, Ref. no. CL 1993/14, SH, Codex Alimentarius Commission, FAO/WHO, Rome. 
Corbella, E. and D. Cozzolino (2006). Classification of the floral origin of Uruguayan honeys by chemical and physical characteristics combined with chemometrics. LWT- Food Science and Technology, 39: 534-539.

Costa, L.S.M., M.L.S. Albuquerque, L.C. Trugo, L.M.C. Quinteiro, O.M. Barth, M. Ribeiro and C.A.B. De Maria (1999). Determination of non-volatile compounds of different botanical origin Brazilian honeys. Food Chem., 65 (3): 347-352.

Crane, E. (1979). A comprehensive survey. Heinemann Intern. Bee Res. Ass. (IBRA). London,3: 76.

Crane, E. (1990). Bees and Beekeeping. Scientific, Practice and World Resources. First ed., Heinemann Newnes, Halley Court, Jordan Hill, Oxford OX2 8EJ, London, UK.

Fallico, B., M. Zappala, E. Arena and A. Verzera (2004). Effects of conditioning on HMF content in unifloral honeys. Food Chem., 85(2):305-313. doi: 10.1016/j.foodchem.2003.07.010.

Finola, M.S., M.C. Lasagno and J.M. Marioli (2007). Microbiological and chemical characterization of honeys from central Argentina. Food Chem., 100 (4):16491653.

Gilbert, J., M.J. Shepherd, M.A. Wallwork and R.G. Harris (1981). Determination of the geographical origin of honeys by multivariate analysis of gas chromatographic data on their free amino acid content. J. Apicultural Res., 20: 125135.

Goodall, I., M.J. Deniss, I. Parker and M. Sharman (1995). Contribution of high performance liquid chromatographic analysis of carbohydrates to authenticity testing of honey. Journal of Chromatography A, 706: 353-359.

Harmonized methods of the international honey commission (2009). Determination of sugars by HPLC. pp:46.

Kaakeh, W. and G.G. Gadelhak (2005). Sensory evaluation and chemical analysis of Apis mellifera honey from the Arab Gulf Region. J. Food Drug Anal., 13 (4): 331-337.

Kamal, A., S. Raza, N. Rashid, T. Hameed and M. Gilani (2002). Comparative study of honey Collected from different flora of
Pakistan. Online Journal of Biological Sciences, 2: 626-627.

Krell, R. (1996). Value-added products from beekeeping. FAO Agricultural Services Bulletin No. 144, Rome, ISBN: 92-5103819-8.

Kucuk, M.K., S. Kolayl, S. Karaoglu, E. Ulusoy, C. Baltac and F. Candan (2007). Biological activities and chemical composition of three honeys of different types from Anatolia. Food Chem., 100: 526-534.

Moniruzzaman, M., M.dl. Khalil, S.A. Sulaiman and S.H. Gan (2013). Physicochemical and antioxidant properties of Malaysian honeys produced by Apis cerana, Apis dorsata and Apis mellifera. BMC Complement Altern Med., 13:43. February 23. doi: $10.1186 / 1472-6882-13-43$.

Muli, E., A. Munguti and S.K. Raina (2007). Quality of Honey Harvested and Processed Using Traditional Methods in Rural Areas of Kenya. Acta Vet. Brno, 76: 315-320.

Nelly, S., K. Heaton, and J. Hoogewerff (2005). Tracing the geographical origin of food: The application of multi-element and multi-isotope analysis. Trends in Food Science and Technology, 16: 555567.

Rossano, R., M. Larocca, T. Polito, A.M. Perna, M.C. Padula, G. Martelli and P. Riccio (2012). What Are the Proteolytic Enzymes of Honey and What They Do Tell Us? A Fingerprint Analysis by 2-D Zymography of Unifloral Honeys. PLoS One, 7(11):e49164. doi: 10.1371 / journal.pone.0049164.

Rodgers, P.E.W. (1979). Honey quality control. In: Crane, E. (Ed.), Honey: A Comprehensive Survey. Heinemann, London, pp:314-325.

Saxena, S., S. Gautam and A. Sharma (2010). Physical, biochemical and antioxidant properties of some Indian honeys. Food Chem., 118(2):391-397. doi: 10.1016/j.foodchem.2009.05.001.

Senyuva, H.Z., J. Gilbert, S. Silici, A. Charlton, C. Dal, N. Gurel and D. Cimen (2009). Profiling Turkish honeys to determine authenticity using physical and chemical characteristics. J. Agric. Food Chem., 57: 3911-3919. doi:10.1021/jf900039s. 
Serrano, S., R. Espejo, M. Villarejo and M.L. Jodral (2007). Diastase and invertase activities in Andalusian honeys. Int. J. Food Sci. Technol., 42:76-79.

Schade, JE, GL Marsh and JE Eckert (1958). Diastase activity and hydroxymethylefurfural in honey and their usefulness in detecting heat alteration. J. Food Res., 23:446-464.

Taha. AA, Asmaa Eissa, (2011). Chemical and physical properties of some Egyptian and Libyan honeys. J. Plant Prot. and Path., Mansoura Univ., 2(8): 731-740.

Terrab, A., A.F. Recamales, D. Hernanz and F.J. Heredia (2004). Characterisation of Spanish thyme honeys by their physicochemical characteristics and mineral contents. Food Chemistry, 88: 537-542.

Tosi, E., M. Ciappini, E. Re and H. Lucero (2002). Honey thermal treatment effects on hydroxymethylefurfural content. Food Chem., 77: 71-74.

Vorlova, L. and A. Pridal (2002). Invertase and diastase activity in honeys of Czech province. Acat Univ. Agric. Et
Silviculturae Medelianae Brunensis Sbornik. Rodnik L 8, Rodnik L Cislo 5.

White, J.W. Jr, and W.D. Landis (1980). Honey Composition and Properties. Beekeeping in the United States, Agriculture Handbook Number 335, Revised October, pp:82-91.

White, JW and MH Subers (1963). Studies on honey inhibine. A chemical assay. J. Apic. Res., 2:93-100.

White, JW, M.L. Riethof, M.H. Sobers and I. Kushnir (1962). Composition of American honeys. U.S., Dept. Agric., Tech. Bull., pp: 1-124.

Winkler, O. (1955). Beitrag zum Nachweis und zur Bestinunung von Oxymethylufural in Honig und Kunsthonig $z$. Lebensmittelunters. u. Porsch, 102:161-167.

Woodcock, T., G. Downey, JD Kelly and C. O'Donnell (2007). Geographical classification of honey samples by nearinfrared spectroscopy: A feasibility study. J. of Agric. and Food Chem., 55: 91289134. 


\section{تقييم جـودة بعض الأعسـال المصرية و السعودية}

عمـرو أحمد طـه(1) ، نجلاء الأحمدى غزالةة(1) ، أمانى سعد مصطفى أبوليلة)(1) ،

حسن محمد فتحى (2)

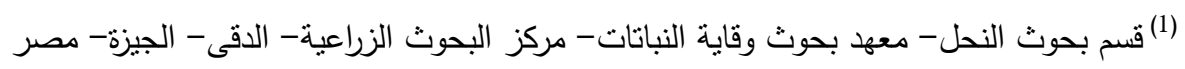

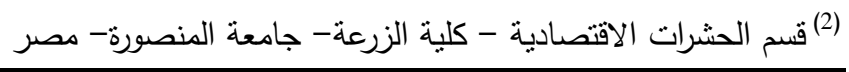

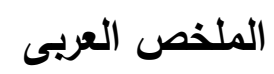

أجريت هذه الدراسة بهدف تقييم بعض الخصائص الفيزيقة والكيميائية لعسل القطن المصرى الأحادى المصدر

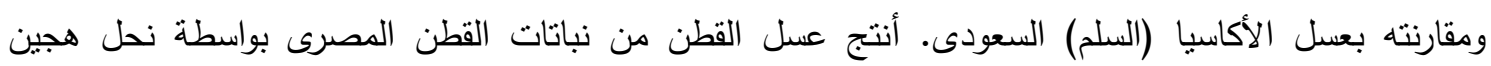

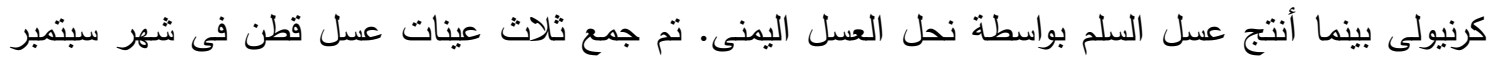

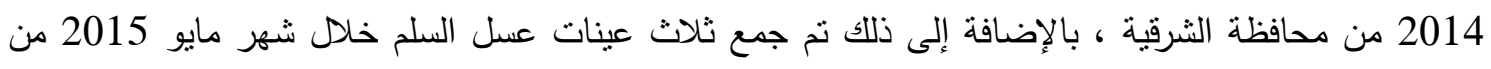
منطقة صابيا، المنطقة الجنوبية ، المملكة العربية السعودية.

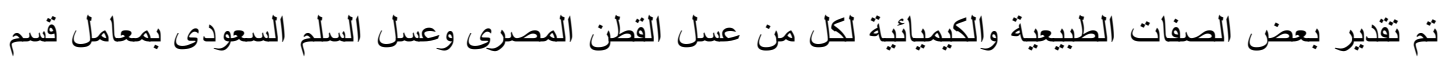

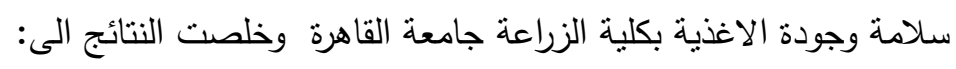

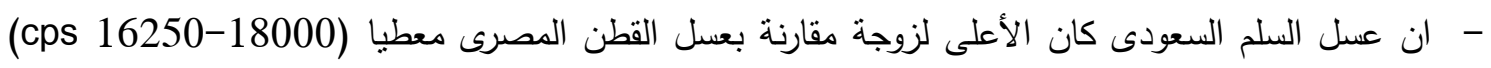

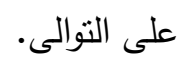

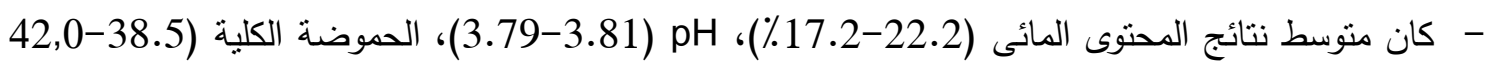

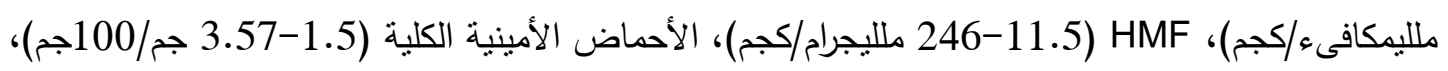
متوى المعادن الكلية (0.8-0.36\%) لكل من عسل القطن و السلم على التوالى.

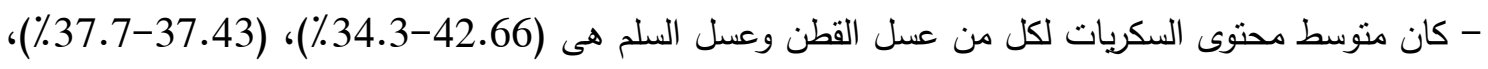

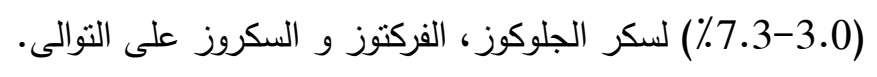

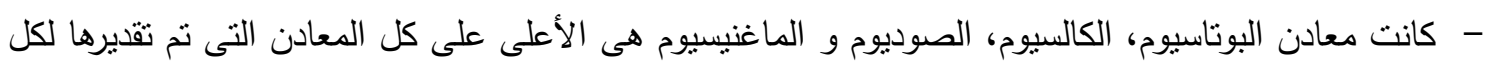
من عنل القطن وعسل السلم على التوالى.

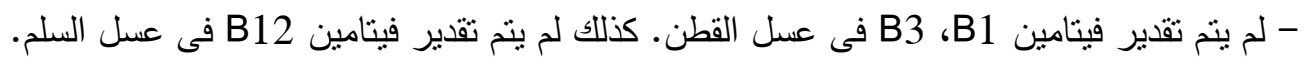

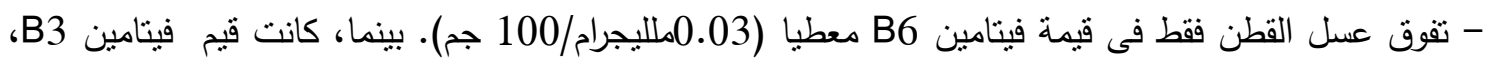

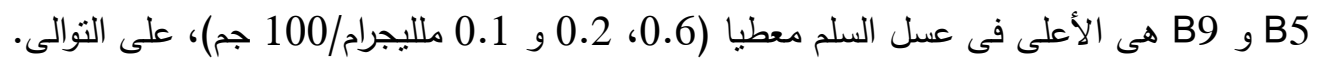

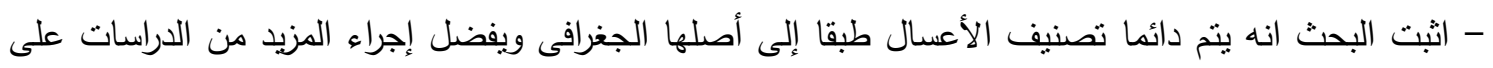

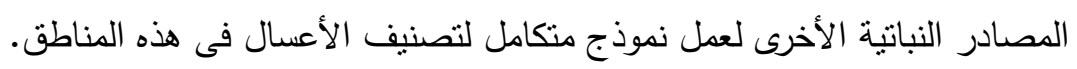

